\title{
Reasons and meanings attributed by women who experienced induced abortion: an integrative review*
}

\author{
Motivos e significados atribuídos pelas mulheres que \\ vivenciaram o aborto induzido: revisão integrativa \\ Motivos y significados atribuidos por las mujeres que \\ experimentaron el aborto inducido: revisión integradora
}

Sandra Elisa Sell ${ }^{1}$, Evanguelia Kotzias Atherino dos Santos ${ }^{2}$, Manuela Beatriz Velho ${ }^{3}$, Alacoque Lorenzini Erdmann ${ }^{4}$, Maria $^{2}$ de Jesus Hernandes Rodriguez ${ }^{3}$

* Extracted from the dissertation "O mundo da vida de mulheres que induziram o aborto: um estudo fenomenológico social," Post-Graduate Program in Nursing, Universidade Federal de Santa Catarina, 2013

${ }^{1}$ Master's in Nursing, Post-Graduate Program in Nursing, Universidade Federal de Santa Catarina, Florianópolis, SC, Brazil.

${ }^{2}$ Doctorate Professor, Undergraduate Course and Post-Graduate Program in Nursing, Universidade Federal de Santa Catarina, Florianópolis, SC, Brazil.

${ }^{3}$ Doctorate in Nursing, Post-Graduate Program in Nursing, Universidade Federal de Santa Catarina, Florianópolis, SC, Brazil.

${ }^{4}$ Doctorate Professor, Post-Graduate Program in Nursing, Universidade Federal de Santa Catarina, Florianópolis, SC, Brazil.

\section{ABSTRACT}

Objective: Identifying the contribution of developed research on what motivates women to induce an abortion and the meaning attributed to these experiences in their lives. Method: An integrative review conducted in MEDLINE/PubMed, LILACS, BDENF, CINAHL and SciELO databases, covering the periods from 2001 to 2011. Results: We selected and analyzed 11 studies with selection criteria being reasons given by women for inducing abortion and/or the meaning attributed to this experience in their lives, including social, religious, ethical and moral aspects related to this practice, as well as the suffering experienced from the experience. The illegality of abortion is identified as a risk factor for unsafe abortions, reaffirming this issue as a public health and social justice problem. Conclusion: Results evidence aspects that can contribute to improving health quality and ratify the importance of research to support nursing practices.

\section{DESCRIPTORS}

Abortion, Induced; Women; Risk Factors; Nursing Care; Review.

\section{Corresponding author:}

Sandra Elisa Sell

Rua Desembargador Nelson Nunes, 160 -

Centro

CEP 88020-770 - Florianópolis, SC, Brazil

sandres.sell@gmail.com 


\section{INTRODUCTION}

Abortion has been recognized worldwide as a public health problem since 1994, when the International Conference on Population and Development was held in Cairo. This recognition is primarily caused by the physical and emotional consequences of abortion that can result in irreversible consequences, and even death for women ${ }^{(1)}$. A fact that has been reaffirmed in every new research, with results suggesting that low socioeconomic position is directly related to abortion being performed in unsafe conditions ${ }^{(2-3)}$. Induced abortion in its definition is the act of terminating a pregnancy by an external and intentional reason before extra uterine viability ${ }^{(1)}$.

Despite the historical reports which tell us that the voluntary termination of pregnancy has occurred in all cultures and at all times, at times it occurs, legally and in a culturally accepted way, at other times it is performed in violent and repulsive ways ${ }^{(4)}$. It is worth pointing out that in Brazil abortion is only legal in three special cases: when pregnancy is a result of rape, when there are proven risks of death to the mother ${ }^{(5)}$ and in cases of pregnancies with an anencephalic fetus ${ }^{(6)}$. However, the restriction of the law has not curbed secret and unsafe abortion practices, thereby maintaining maternal mortality at high levels. It is necessary to consider that the abortion numbers are always estimated (or underestimated), since it is illegal in many countries.

Estimates show that about 42 million abortions occur annually in the world, between spontaneous and induced ${ }^{(7)}$. Experts believe that 20 million of these are illegal ${ }^{(7-8)}$, and 6 million occur annually in Latin America ${ }^{(9)}$.

In Brazil, research shows that unsafe abortions represent the 4th most causes of maternal mortality in the country ${ }^{(10)}$.

According to the platform of the Fourth World Conference on Women - Beijing (1995), the practice of abortion is involved in socio-economic, cultural, legal, ethical and religious contexts. The denial of rights to health, autonomy, and free and voluntary motherhood, admittedly fundamental rights of women, has helped to aggravate this situation.

Abortion involves aspects of moral and religious nature, the subject of strong social sanction, associating difficulties on this account for women, particularly in illegal contexts, such as in Brazil ${ }^{(11)}$.

The termination of pregnancy has been characterized as a controversial issue, in which there is conflict between fundamental and human rights. Legally, the solution to this problem can only be given by the weighting of the principle of proportionality ${ }^{(12)}$. The practice of abortion ends up introducing a conflict of morally established duty, which brings guilt to women from their individual decision not to opt for keeping the pregnancy, because the social expectation of motherhood is seen as a wonderful and ideal experience, and the mother must play her role to perfection ${ }^{(13)}$.

Research has shown that the arguments for or against abortion have not favored women in order to mitigate the physical and/or emotional trauma arising from this experience, and health services have been identified as inept in this process ${ }^{(14)}$.
Discrepancies occur at all levels, however, a study that assessed the attitudes of health professionals showed the inconsistency between the thinking and acting of these professionals, citing the rate of those who would accept (or have already accepted) to induce abortion under the circumstances in which they were personally involved and the rate of those who would be willing (or are willing) to assist patients who seek to realize the termination of a legal and safe pregnancy ${ }^{(15)}$.

Researchers have drawn attention to the quality of health care for women, especially with regard to reproductive characteristics and the pre- and post-abortion process, affirming the need to implement urgent strategies ${ }^{(3)}$.

Thus, in order to subsidize the reflection on the practice of abortion in Brazil, we decided to conduct this literature integrative review in order to identify the contribution of the developed research on the reasons for abortion and the meaning of this experience for the women who had chosen to induce it.

We believe in the need to advance in research that values humanistic aspects involved in care for women having an abortion and, therefore, it is necessary to recognize the advances and/or scientific gaps to better define the paths that need to be laid out, thus subsidizing our future actions.

\section{METHOD}

This is an integrative review of literature, which is a research method that enables the synthesis of a subject state of knowledge, and to identify gaps that need to be filled with new studies. Therefore, we should follow the same methodological rigor of original research, providing readers with contributions to the advancement of clinical practice $^{(16)}$.

This integrative review of literature followed a protocol defined by the five members of the research and was developed by covering six steps ${ }^{(17)}$ :

In the first stage, we sought to issue the identification and selection of the research question on the abortion issue: What are the motivations for inducing abortion and the meanings attributed to this experience by women who have experienced it?

In the second stage, which is defining inclusion and exclusion criteria of the study, we defined inclusion criteria as: studies published in Brazil, between 2001 and 2011 in Portuguese, English and Spanish, which had indications that have investigated the reasons for induced abortion and/or its significance for women who have experienced it in the summary; regardless of research method; which had the title and abstract indexed in databases. The studies that only addressed spontaneous abortion; legal interruption of pregnancy and articles related to termination of pregnancy with risks of harm to maternal health, as in cases of preeclampsia, eclampsia and cervical cancer, along with duplicate studies were excluded.

Before starting the research itself, the group sought the support and guidance of a health specialist librarian to help define the search strategy to be used. The search for articles was conducted online in the following databases: Literature 
of Latin America and the Caribbean (LILACS), Nursing Databases (BDENF), Medical Literature on Line (MEDLINE), Cumulative Index to Nursing and Allied Health Literature (CINAHL) e Scientific Electronic Library Online (SciELO).

To search in LILACS and BDENF databases, we used the Health Sciences descriptor (DeCS - in Portuguese) "aborto induzido," cross-referencing the search with the words: mulher $\$$, adolescente $\$$, adolescência, provocad $\$$, induzid $\$$, aborto, gestação, interrupção, voluntária and gravidez. The $\$$ symbol is a resource used in database research. It is recognized by the search engine as a command to search for words originating from that root, such as mulher $\$$ : is understood as the search for woman and women. Adolescente\$: searches for teenager and teenagers. Provocad $\$$ : searches for intentional, intentionally. Induzid\$: searches for induces, induced. For MEDLINE and CINAHL databases, the following meSH terms were used: abortion and induced.

In SciELO, the search occurred with the use of the words (Intention\$ OR induce\$) AND (abortion OR pregnancy) OR (voluntary AND interruption AND gestation) in the index field, cross-referenced with the words (teenager\$ OR woman $\$$ OR adolescence), in the index field.

635 articles (titles) were found. From this identification, all abstracts were accessed through the internet. The reading procedure for identification of the inclusion criteria was done by three study participants with training in nursing and specialists in women's health. The members of the research agreed that in case of disagreement over the inclusion or exclusion of any of the articles, a new closed reading would be held, and the divergence remained would be held to a vote. We emphasize that this did not need to happen, as 11 articles met the inclusion criteria. In the third stage, we proceeded to define the information to be extracted from the selected studies. Therefore, the information was cataloged in bibliographic record, including the following items: identification of authors and their academic backgrounds, periodic identification and year of publication, language in which it was published and country of origin, descriptors, objective of the research, design type and theoretical analysis, site of the research, the data collection period, study subjects, delimitation of the sample, the method, the instrument used for data collection, how the analysis of data was performed, and the ethical principles involved. We sought to identify the main findings, conclusions, recommendations for practice, suggestions for further research and, finally, the difficulties presented.

In the fourth stage of assessing studies, there was the completion and evaluation of bibliographic records, which made for indispensable access to the full text of selected studies. Five members of the study actively participated in this stage. Through critical analysis and by noting the methodological aspects and the convergence between the results, we were able to further categorize the motivations for inducing abortion and significance of the lived experience for women who had induced an abortion.

The fifth step consisted in discussion and interpretation of results. Thus, the recommendations were prepared for clinical practice from the conclusions drawn from the review, making suggestions for further research to fill the gaps found in this review.

The sixth stage of the integrative review was the presentation of the evidence available in the form of a summary and presentation of results.

\section{RESULTS}

By analyzing the 11 selected studies, we observed that six of them used a quantitative approach; four used a qualitative approach, and one study used a mixed quantitative/ qualitative approach. Among the studies with a qualitative approach, one used the phenomenological theoretical framework, not associating any author of specific phenomenology and the other three had disclosed theoretical frameworks. The most frequent descriptors were: abortion/ miscarriage/induced abortion/intentional, women's health/ reproductive health. Were used semi-structured questionnaires for data collection in eight studies, structured interviews in two studies, and one study used a guiding question testimony. Among the 11 studies, a total of 450 subjects were directly approached in the hospital, during hospitalization for conducting abortion. Other research environments were schools, districts and municipalities. The ages of the subjects ranged from 12 to 54 years. Five studies addressing motivations and meanings attributed to abortion experiences for women were found; five studies addressing only the motives for abortion and one study addressing the meanings attributed to the experience of abortion by the women. Chart 1 shows some of the data analyzed.

Regarding the objectives set out by the researchers of the selected studies, one perceives the concern to seek scientific answers to everyday issues that permeate the current challenges in health.

Thus, some studies have sought to identify what motivates women to turn to unsafe and induced abortions focusing on different angles: through reflection on the physical and emotional effects; the context of domestic violence; the socioeconomic and cultural conditions; and also the context of illegality in which abortion is inserted in our country.

The finding of this review resulted in two categories: motivations for induced abortion and meanings attributed to the experience by women who had an induced abortion.

Motivations for induced abortion: studies that have attempted to understand the motivations for abortion have arrived at very convergent results, with the most cited being: the rejection of pregnancy itself; abortion as a contraceptive method; the lack of fellow support; the difficulty of access to family planning services or emergency contraception; socioeconomic factors (unemployment or fear of losing their jobs); fear of the reaction of parents or disappointing them; domestic violence (sexual, physical, psychological and sexual coercion perpetrated by intimate partners and family); marital status (being single or being in a complicated relationship); the desire to not drop out of school, among others less cited.

Two studies ${ }^{(20,22)}$ have shown that most women who had induced abortion did not plan pregnancy, although some 
expressed the desire to keep it. However, giving in to the pressures imposed by the situation they were in, they eventually did it against their will. One study, conducted at the University of São Paulo (USP) ${ }^{(14)}$, showed that the difficulty of coping with both the pregnancy and having induced an abortion can affect the mental health of these women, being at risk for developing anxiety and depression, and these may be demonstrated even years after the fact.

Chart 1 - Description of studies included in the Integrative Literature Review - Florianópolis, SC, Brazil, 2012.

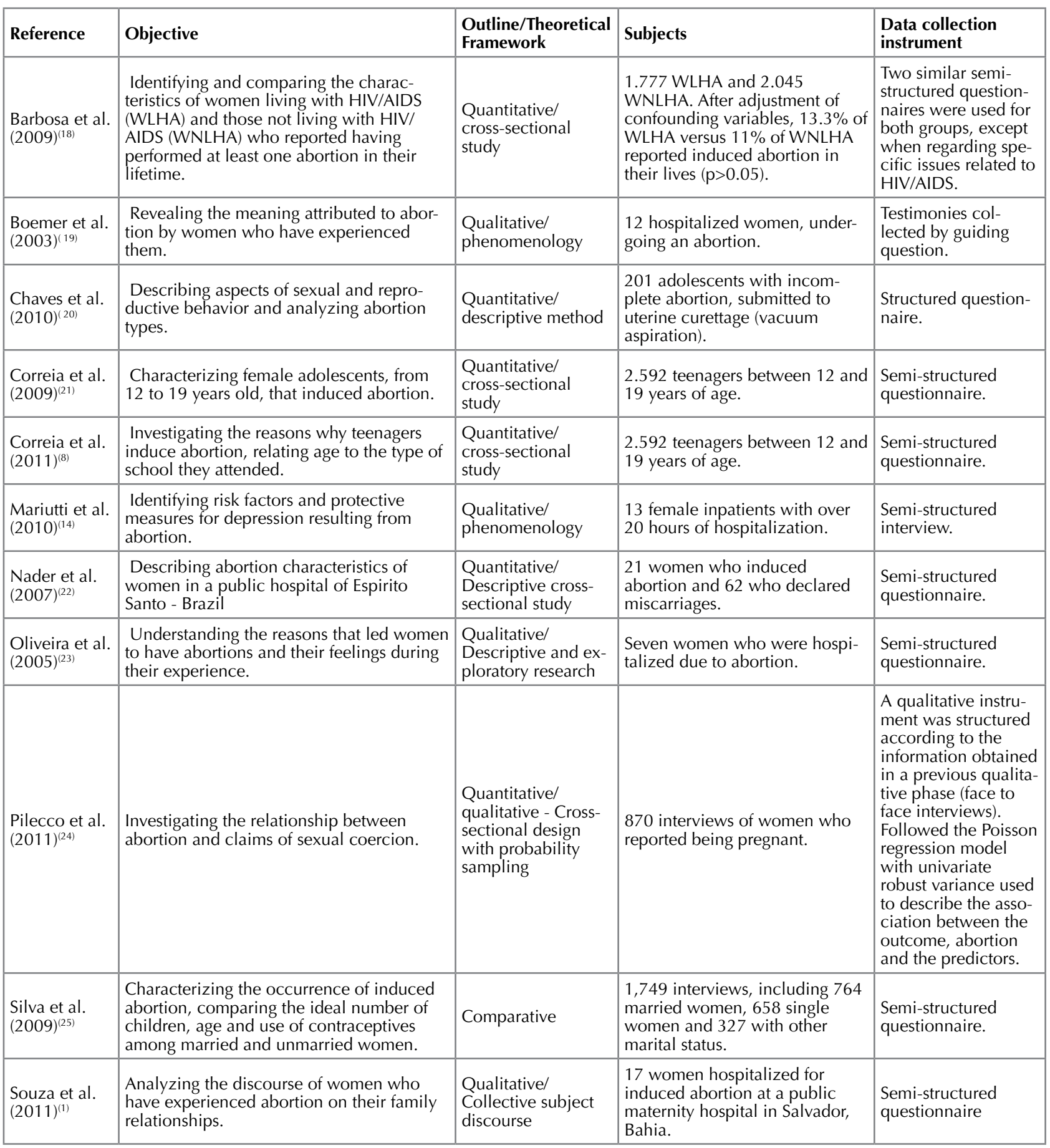

The lack of information on family planning and the lack of access to contraceptive methods contribute to the increase of these pregnancies and consequently to the increase of abortions in unsafe conditions ${ }^{(22-25)}$.

The decision to abort, often encouraged by the partner, shows that there was no planning carried out by the couple ${ }^{(22)}$. In this context, there is often domestic violence present, identified in the pressure exerted by the partner and family, which overrides the desire and the freedom of women who without support to maintain pregnancy surrender to passivity, overcome by feelings of guilt, shame, anxiety, low self-esteem and humiliation. The moral patriarchy is also cited in some studies ${ }^{(1,8,22,24)}$, strongly argued by the influence of the values passed from each generation, in the formation of Brazilian society. Pregnancy is not seen as a possibility for a woman who has no reliable partner, 
who does not have financial stability, which is very young, or already has other children, representing dishonor and shame to the family.

As for the discussion about the context of illegality and criminality to which induced abortion is inserted, a redirected look at the situation when studies approach women in a face to face relationship can be observed (a direct interview through dialogue) or when seeking to understand the phenomenon, by analyzing the context in which the women are in. We feel it is necessary to highlight reports of many women concerning fears related to inducing abortion: fear of dying, of being judged by society, of being despised by health professionals, of being punished by God, and their parents' reaction, but the fear of being criminalized in court does not appear in any studies.

A study of secret abortion practiced by adolescents ${ }^{(19)}$ argues that this process should be investigated, associating it more to victims than crime, since women are often repressed and yield to having an abortion even against their will.

We observed in this review that the higher the education, the greater the risk of inducing abortion, touted as a possibility for young people who discover an unplanned pregnancy, weighing on the decision of continuing in school or progressing their career ${ }^{(19)}$.

Meanings attributed to the experience by women who had induced abortion: of the 11 studies classified to integrate this review, five contemplate the question of the meaning of the experience of induced abortion for women $^{(1,14,19,22-23)}$. Four were conducted with qualitative design and one with quantitative design. The most occurring meanings attributed to the experience were feelings of guilt, fear of dying, fear of punishment from God, regret, remorse, repentance, physiological and existential pain, fear of being blamed by others and shame. Other feelings were expressed on a smaller scale, but no less worrying, while also demanding socio-political and health actions: sense of abandonment, tension, loss of faith, low self-esteem, hostility, anger, despair, helplessness, hurt and bad feelings towards people involved in the situation, a desire to break the relationship with the partner, loss of libido, inability to forgive, nervousness, nightmares, depression, a feeling of loss, sadness, loneliness, hospitalization discomfort, desire to reconsider their life plans, suicidal impulses and relief.

We emphasize that all the selected studies presented recommendations for practice and emphasized the importance of communication between the various social sectors, highlighting the family, the school environment, health services, and other human living spaces in which the precepts of justice, dignity and equality can be exercised ${ }^{(8)}$. Recommendations also cited by some authors were for better care for women in health services, offering care that takes into account the emotional aspects and the possibility of violence suffered by women ${ }^{(1,14)}$.

Of the studies analyzed, five make suggestions for further research, which are: studies evaluating what the parents of women who have abortions think and reproduce, such as the fear of parental reaction which appeared in a strong way ${ }^{(8,19)}$. Others suggest greater investment in research that address the meaning of the experience for women and greater attention to failures in family planning as a whole ${ }^{(18,21-22)}$. And still, topics identified as risk factors for abortion such as men and their role in family planning, domestic violence and sexual coercion are all areas that need to be investigated ${ }^{(19,24)}$.

\section{DISCUSSION}

The consensus among authors is that the production of scientific knowledge on the subject of abortion represents a guiding principle for health policy, adding scientific knowledge to the concerns of service users awaiting planned actions, and in a universe of needs identified by the subjects themselves.

When we look at the list of feelings triggered in women after abortion, we can see a gap in the image created by common sense, that women who have an abortion are cold and devoid of feelings. The fault, which appeared in five studies $^{(1,14,19,22-23)}$, leads us to infer that the practice of abortion requires attention to the emotional state of women, commonly undervalued. It is known that most of them leave out the abortion and thereby are left subdued and neglected in their real needs. This silence must be respected, as is the need for emotional reorganization ${ }^{(14)}$, but should not blind the professional so much as to believe that this woman does not want or need care beyond their physical body.

The definition given by women that abortion is "an experience flooded by great pain," ${ }^{(14,19)}$ is in line with the other findings in the studies. This reinforces the issue as a public health problem that requires immediate action, starting with the way women are treated in services. Denial of care and attention given by professionals because they are unprepared in not knowing how to deal with their own beliefs and values can trigger a series of feelings that will reflect on the meaning that the woman will give this experience, especially when hospitalization is considered uncomfortable ${ }^{(19)}$. It can cause shame, a fear of being blamed, anger, feelings of abandonment, among other feelings.

The fear of being punished by God with respect to their attitude also appears in the studies that reported the meanings attributed to abortion by women ${ }^{(1,22-23)}$, in which they consider themselves committing a great sin. Therefore, there exists a gap to be rethought by religions, for the moral burden that generates suffering and guilt that does not suit the role of welcoming and consoling comfort that is expected by followers.

The fear of their family's reaction is parallel: value judgments regarding the woman who becomes pregnant without planning and without a stable partner is commonly experienced within the family. Similarly, the model that perpetuates gender inequality means that only women are held responsible for the act of abortion.

The repetition of unplanned pregnancies and abortions suggests a deficit in services with respect to reproductive health and family planning, therefore increasing opportunities for access to knowledge and encouragement for the actual practice of female autonomy including the male figure 
in these discussions is recommended ${ }^{(19,22,25)}$. It is frequently observed that the prevention of pregnancy has been overcome by the practice of abortion, which is being used as a birth control method.

The secrecy of abortion masks the real numbers, and studies have only been conducted on a compartmentalized and regional basis, which makes the results appear different, however compelling, as we take into account that Brazil is a diverse country as to sociodemographic contexts where cultures change in each geographical area. Corroborating this statement, we can see that current studies bring forth the issue of education, differing from studies in previous years and in different communities. This question requires further investment to be evaluated carefully, to if the increase in the cultural level might be favoring the awareness of women's autonomy, or if education is advancing a dissociation from health care and reproductive planning, considering that abortion still causes maternal deaths. Empowering women, the victims of unwanted pregnancies, highlights the lack of conditions in which they have to exercise free choices ${ }^{(1,14,24)}$, and that criminalization does not deter the occurrence and only reinforces the conditions of risk.

Concern over the body, represented by the fear of dying and low self-esteem as cited in four studies ${ }^{(1,14,19,23)}$ does not restrict the practice of abortion. Despair surpasses all other concerns and women become vulnerable to the risks to which they are submitted.

\section{CONCLUSION}

This integrative review was done in order to identify the contribution of developed research on what motivates women to induce abortion and the meaning of the experience in their lives; it emphatically reinforces the need for further studies to demonstrate the lack of sensitivity in society and of health services in general, which have placed the issue of abortion outside the principles of human dignity.

The medical and biological treatment, the inattention given to feelings and the lack of actions related to reproductive health of women are practices that keep occurring in front of abortion prevention.

Understanding the meaning of induced abortion is still a fact little explored by researchers, as noted during the search of articles for this review. The study highlights the need for better understanding of the magnitude of abortion and the socio-demographic situation in which women are inserted.

This synthesis of knowledge brought forth by the studies included in this review highlights the importance of research to support nursing practice and to stimulate further research in understanding the multidimensionality in which induced abortion is inserted.

\section{RESUMO}

Objetivo: Identificar a contribuição das pesquisas desenvolvidas sobre o que motiva as mulheres a induzirem o aborto e o significado desta experiência em suas vidas. Método: Revisão integrativa realizada nas bases de dados MEDLINE/PubMed, LILACS, BDENF, CINAHL e SciELO, compreendendo o período 2001 a 2011. Resultados: Foram selecionados e analisados 11 estudos cujos critérios de seleção apresentavam os motivos alegados pelas mulheres para a indução do aborto e/ou o significado desta experiência em suas vidas, mencionando aspectos sociais, religiosos, éticos e morais ligados a esta prática, bem como o sofrimento decorrente desta vivência. A ilegalidade é apontada como fator de risco para o aborto inseguro, reafirmando a questão como problema de saúde pública e de justiça social. Conclusão: Os resultados evidenciam aspectos que podem contribuir para melhorar a qualidade da saúde e ratificam a importância das pesquisas para fundamentar a prática da enfermagem.

\section{DESCRITORES}

Aborto Induzido; Mulheres; Fatores de Risco; Cuidados de Enfermagem; Revisão.

\section{RESUMEN}

Objetivo: Identificar el aporte de las investigaciones desarrolladas acerca de lo que motiva a las mujeres a inducir el aborto y el significado de esa experiencia en sus vidas. Método: Revisión integradora llevada a cabo en las bases de datos MEDLINE/PubMed, LILACS, BDENF, CINAHL y SciELO, comprendiendo el período 2001 a 2011. Resultados: Fueron seleccionados y analizados 11 estudios cuyos criterios de selección presentaban los motivos alegados por las mujeres para la inducción del aborto y/o el significado de dicha experiencia en sus vidas, mencionando aspectos sociales, religiosos, éticos y morales vinculados a esa práctica, así como el sufrimiento consecuente de esa vivencia. Se apunta la ilegalidad como factor de riesgo para el aborto inseguro, reafirmando la cuestión como problema de salud pública y justicia social. Conclusión: Los resultados evidencian aspectos que pueden contribuir para mejorar la calidad de la salud y ratifican la importancia de las investigaciones para fundamentar la práctica de la enfermería.

\section{DESCRIPTORES}

Aborto Inducido; Mujeres; Factores de Riesgo; Atención de Enfermería; Revisión.

\section{REFERENCES}

1. Souza ZCS, Diniz NMF. Aborto provocado: o discurso das mulheres sobre suas relações familiares. Texto Contexto Enferm [Internet]. 2011 [citado 2012 set. 20];20(4):742-50. Disponível em: http://www.scielo.br/pdf/tce/v20n4/13.pdf

2. Dias TZ, Passini R Jr, Duarte GA, Sousa MH, Faúndes A. Association between educational level and access to safe abortion in a Brazilian population. Int J Gynecol Obstet. 2014;128(3):224-7. 
3. Melo FRM, Lima MS, Alencar CH Jr ANR, Costa FH, Machado, MMT, Heukelbach J. Temporal trends and spatial distribution of unsafe abortion in Brazil, 1996-2012. Rev Saúde Pública [Internet] 2014 [cited 2015 Jan 10];48(3):508-20. Availablefrom: http://www.scielo.br/ pdf/rsp/v48n3/0034-8910-rsp-48-3-0508.pdf

4. Ramírez Fernández CE, Vaillant Rodríguez M, Salas Palacios SR, Meléndez Suárez D, Herrero Aguirre HC. Captación de adolescentes gestantes e interrupción del embarazo durante un quinquenio en la provincia de Santiago de Cuba. MEDISAN [Internet] 2013 [citado 2015 jan. 10];17(9):5010-17. Disponibleen: http://www.bvs.sld.cu/revistas/san/vol17_9_13/san08179.pdf

5. Brasil. Decreto-Lei n. 2.848, de 7 de dezembro de 1940. Código Penal [Internet]. Brasília: Câmara dos Deputados, Centro de Documentação e Informação; 1940 [citado 2011 out. 11]. Disponível em: http://www2.camara.leg.br/legin/fed/declei/1940-1949/decreto-lei-28487-dezembro-1940-412868-normaatualizada-pe.pdf

6. Conselho Federal de Medicina. Resolução n. 1.989, de 10 de maio de 2012. Dispõe sobre o diagnóstico de anencefalia para a antecipação terapêutica do parto e dá outras providências. DiárioOficial da União, Brasília, 14 maio 2012. Seção 1, p. 308-9.

7. Sedgh G, Henshaw S, Singh S, Ahman E, Shah IH. Induced abortion: estimated rates and trends worldwide. Lancet. 2007;370(9595):133845.

8. Correia DS, Cavalcante JC, Egito EST, Maia EMC.Prática do aborto entre adolescentes: um estudo em dez escolas de Maceió (AL, Brasil). Ciênc Saúde Coletiva [Internet]. 2011 [citado 2012 out. 11];16(5):2469-76. Disponível em: http://www.scielo.br/pdf/csc/v16n5/a16v16n5. pdf

9. Sedgh G, Singh S, Shah IH, Ahman E, Henshaw SK, Bankole A. Induced abortion: estimated rates and trends worldwide 1995 to 2008 . Lancet. 2012;370(9816):625-32.

10. Brasil. Ministério da Saúde; Secretaria de Vigilância em Saúde, Departamento de Análise de Situação de Saúde. Saúde Brasil 2011: uma análise da situação de saúde de a vigilância de saúde da mulher. Brasília: Ed. Ministério da Saúde; 2012. Mortalidade materna no Brasil: principais causas de morte e tendências temporais no período de 1990 a 2010; p. 345-58.

11. Menezes G, Aquino EML. Pesquisa sobre o aborto no Brasil: avanços e desafios para o campo da saúde coletiva. Cad Saúde Pública [Internet]. 2009 [citado 2012 jul. 13];25 Suppl 2:S193-204. Disponível em: http://www.scielo.br/pdf/csp/v25s2/02.pdf

12. Bruschi SC, Diniz NM, Lovato NR. O aborto no anteprojeto do novo código penal brasileiro: reflexões jurídicas e bioéticas. Rev BioetDerecho [Internet]. 2013 [citado 2015 jan. 11];(29):35-50. Disponibleen: http://scielo.isciii.es/pdf/bioetica/n29/articulo04

13. BenuteGRG, NomuraRMY, Pereira PP, Lucia MCS, Zugaib M. Aborto espontâneo e provocado: ansiedade, depressão e culpa. RevAssocMedBras [Internet]. 2009 [citado 2012 jul. 14];55(3):322-7. Disponível em: http://www.scielo.br/pdf/ramb/v55n3/v55n3a27.pdf

14. Mariutti MG, Furegato ARF. Fatores protetores e de risco para depressão da mulher após o aborto. RevBrasEnferm [Internet] 2010 [citado2012 jul. 13];63(2):183-9. Disponível em: http://www.scielo.br/pdf/reben/v63n2/03.pdf

15. Cacique DB, Passini Junior R, Osis MJMD. Opiniões, conhecimento e atitudes de profissionais da saúde sobre o aborto induzido: uma revisão das pesquisas brasileiras publicadas entre 2001 e 2011. Saúde Soc [Internet]. 2013 [citado 2015 jan. 11];22(3):916-36. Disponível em: http://www.revistas.usp.br/sausoc/article/view/76487/80224.

16. Polit DF, Beck CT. Essentials of nursing research. Methods, appraisal and utilization. Philadelphia: Lippincott; 2006. Using research in evidence-based nursing practice; p. 457-94.

17. Ganong LH. Integrative reviews of nursing research. Res Nurs Health. 1987;10(1):1-11.

18. Barbosa RM, Pinho AA, Santos NS, Filipe E, Villela W, Aidar T. Aborto induzido entre mulheres em idade reprodutiva vivendo e não vivendo com HIV/AIDS no Brasil. Ciênc Saúde Colet [Internet] 2009 [citado 2012 jul. 13];14(4):1085-99. Disponível em: http://www.scielo.br/ $\mathrm{pdf} / \mathrm{csc} / \mathrm{v} 14 \mathrm{n} 4 / \mathrm{a} 10 \mathrm{v} 14 \mathrm{n} 4 . \mathrm{pdf}$

19. Boemer MR, Mariutti MG. A mulher em situação de abortamento: um enfoque existencial. RevEscEnferm USP. 2003;37(2):59-71.

20. Chaves JHB,Pessini L, Bezerra AFS, Nunes R. Abortamento provocado e o uso de contraceptivos em adolescentes. RevBrasClin Med. 2010;8(2):94-100.

21. Correia DS, Monteiro VGN, Egito EST, Maia EMC. Aborto provocado na adolescência: quem o praticou na cidade de Maceió, Alagoas, Brasil. Rev Gaúcha Enferm [Internet]. 2009 [citado 2012 jul. 14];30(2):167-74. Disponível em: http://www.seer.ufrgs.br/index.php/RevistaGauchadeEnfermagem/article/view/7150/6672

22. Nader PRA, Blandino VRP, Maciel ELN. Características de abortamentos atendidos em uma maternidade pública do município de Serra ES. RevBrasEpidemiol [Internet]. 2007 [citado 2012 jul. 16];10(4):615-24. Disponível em: http://www.scielo.br/pdf/rbepid/v10n4/18.pdf

23. Oliveira MS, Barbosa ICFJ, Fernandes AFC. Razões e sentimentos de mulheres que vivenciaram a prática do aborto. Rev RENE. 2005;6(3):2330.

24. Pilecco FB, Knauth DR, Vigo A. Aborto e coerção sexual: o contexto da vulnerabilidade entre mulheres e jovens. Cad Saúde Pública. 2011;27(3):427-39.

25. Silva RS, Vieira EM. Frequency and characteristics of induced abortion among married and singles women in São Paulo, Brazil. Cad SaúdePública [Internet]. 2009 [cited 2012 July 16];25(1):179-87. Available from: http://www.scielo.br/pdf/csp/v25n1/19.pdf 